\title{
Preserving Scenic Areas: The Adirondack Land Use Program
}

The pursuit of rural pleasures by city-dwellers, which brings with it crowding and commercial development, threatens to destroy the availability of those pleasures. New York State has undertaken a program of land use regulation intended to safeguard the large Adirondack Mountain region from this threat. This Note will study certain aspects of that program which recommend it to all states having scenic, uncongested areas similarly in need of protection. Part I will analyze the program's background, goals, and mechanisms. The program marks an important shift from local to regional regulation, and provides an integrated set of controls more far-reaching than any previously used to maintain large private land areas in a relatively unaltered, esthetically pleasing condition. Part II will show that the program is skillfully framed to disarm two constitutional objections-exclusion and "taking"-which have plagued environmentally oriented land use regulations in the past.

\section{The Program}

\section{A. Background and Structure}

The Adirondack Park is a six million acre region of northern New York comprising all lands enclosed within an irregularly polygonal boundary drawn by the legislature. ${ }^{1}$ It embraces 92 towns and is larger than Massachusetts, New Hampshire, New Jersey, or any of four other states. ${ }^{2}$ Thirty-eight percent of this land is owned by New York State; the remaining 62 percent is private. ${ }^{3}$ Until quite recently the fact that the 3.7 million acres of private land were part of a "park" had little effect on what activities could legally be carried out on them; land

1. N.Y. Adirondack Park Agency, Land Use Planning for the Adrondack Park 3 (1974). The park's boundary is defined in N.Y. ENvironmental CoNSERvation Law $\$$ 9-0101 (McKinney 1973).

2. N.Y. Adirondack Park Agency, Annual Report 1973-74, at 18, 30; U.S. Bureau of the Census, Dep't of Commerce, Statistical Abstract of the United States 172 (1974).

3. N.Y. Adirondack Park Agency, Land Use Planning for the Adirondack Park 3 (1974). One must not confuse the regulations applying to the park's private landsthe subject of this Note-with the "forever wild" clause of the N.Y. Constitution (art. $\mathrm{XV}, \S \mathrm{I}$ ), which relates to management of the state's Adirondack holdings. This clause prohibits all commercial development, and all alterations of the land that would involve removing timber to "any material degree." Association for the Protection of the Adirondacks v. MacDonald, 253 N.Y. 234, 238, 170 N.E. 902, 904 (1930). 
use was almost entirely unregulated. ${ }^{4}$ This situation prompted Governor Rockefeller in 1968 to create a special commission which made an exhaustive two-year study of the region's prospects. ${ }^{5}$ The commission reported that the pressure of development in the Adirondacks posed "a grave and growing threat to the entire Park," and pointed out how other scenic and natural areas were similarly threatened nationwide. ${ }^{6}$ This pressure arises as an ever more urbanized and affluent population seeks the recreational and esthetic pleasures provided by scenic and natural areas; as a result, an area may lose its attraction altogether. An important menace is the growth of tourist-oriented "strip" development along highways. ${ }^{7}$ But the biggest threat in the Adirondacks appeared to be uncontrolled vacation home development, which the commission stated might easily "destroy the Park."

One of the commission's principal recommendations was that the state itself assume primary responsibility in the regulation of private land use in the park rather than rely on the efforts of local governments. ${ }^{9}$ This proposal represented a substantial departure from estab. lished methods of land use control, under which plans are conceived, enacted, and administered almost entirely by local units under broad state enabling statutes. Two main reasons were given for this depar-

4. The term "Adirondack Park" dates from an 1892 statute in which it was used only to refer to state lands. Ch. 707, $\$ 8$, [1892] Laws of N.Y., 115th Sess. 1460-61. But in 1912 private lands came to be included within the designation as well, although the statement of purpose or policy regarding the park referred only to the state lands. Ch. $444, \$ 51$ [1912] Laws of.N.Y., I35th Sess. 890-92, as amended, N.Y. ENvikonMeNTAL Conservitiox LAw $\$ 9-0101$ (McKinney 1973). For nearly 60 years after this 1912 change the state paid little attention to those private lands; the only law enacted regulating land use in the whole park area was a 1924 statute giving the Conservation Department broad authority to regulate off-premise advertising signs in the park to keep it "open, clean and in good order for the welfare of society." Ch. 512 [1924] Laws of N.Y., 147th Sess. 931, as amended, N.Y. Environmental Conservation Law \$ 9-0305 (Mckinney 1973); N.Y. TEMPORARY STUDY COMM'N, THE: Future OF THE ADIRONDACK PARK 28 (1970) [hereinafter cited as THE FUTURE OF THE ADIRONDACK PARK].

5. The Future of The Adirondack PARK, supra note 4, at 3.

6. Id. at 26,28 .

7. This development chiefly comprises motels, gasoline stations, novelty shops, and "wild-west"-type tourist attractions; examples in the Adirondacks of its having reached an advanced stage can be found between Pottersville and Schroon Lake along U.S. Route 9, and along the three highways leading into Lake Placid. The irony involved in this sort of development is that its economic success is largely dependent on the presence of travelers seeking to enjoy the land appearance it is gradually obliterating. For a discussion of the nationwide dimensions of this problem, and of the necd for land use regulation to ameliorate it, see 5 U.S. Nir'L TourisM Rfsources RFv. Commi. Destination U.S.A. 17-18, 27-28 (1973); 1 id. 38-45.

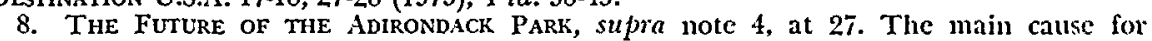
concern regarding vacation homes is their tendency to spring up in those places which are closest to being in a pristine state-for the reason that such places are often the most attractive. Their uncontrolled development poses a particular threat to the large spaces of unbroken wild forest which still exist in the Adirondacks (see C. TUNN,IRD \& B. Pushkarev, Man-Made AMierica: Chaos or Control? 29 (1963) (map of U.S. wilderness areas, defined as land more than five miles from any motorable road, railroad or navigable waterway)), the presence of which must rank as one of the region's principal scenic and recreational resources.

9. The Future of The Adirondack Park, supra note 4, at 25-30. 
ture. First, since development on the park's "vast open space acreages" can affect the well-being of the state as a whole, control of its direction should not be left entirely in the hands of local communities whose interest with regard to some proposed developments might be adverse to the state's. ${ }^{10}$ Second, geographically large local units with small populations and limited financial resources find it difficult to establish effective planning and control over the whole of their area. The commission in this regard noted that 39 Adirondack towns have a population less than 1000 and four less than $100 .{ }^{11}$ This second reason for favoring regional controls no doubt applies to large areas of the United States ${ }^{12}$ which have a low population density similar to that of the Adirondacks. Following the commission's specific proposals regarding planning authority, ${ }^{13}$ the legislature in 1971 created the Adirondack Park Agency, ${ }^{14}$ gave it certain "interim" land use control powers, ${ }^{15}$ and charged it with formulating a "land use and development plan" applicable to all the private lands in the park. ${ }^{16}$ In 1973 the agency submitted its plan, which, together with various "recommendations for implementation," was cast into statutory form and enacted by the legislature the same year. ${ }^{17}$

But the commission did not intend to vest permanently all control of Adirondack land use in a new state bureaucracy, or to strip the local communities of all their traditional powers; a complementary relationship was desired instead. ${ }^{18}$ The 1973 statute closely follows

10. Id. at 30 .

11. Id. at 27 .

12. See GOODE's WorLd ATLAs 58 (12th ed. 1968) (U.S. population density map).

13. See The Future of THE Adrondack PARK, supra note 4, at 9 (Recommendations 1-3); ch. 706, $\$ \$ 803-06$ [1971] Laws of N.Y., 194th Sess. 1855-57, as amended, N.Y. ExECuTIVE LAW $\$ \$ 803-05,815$ (ACKinney 1974).

14. Ch. 706, \$ 803 [1971] Laws of N.Y., 194th Sess. 1855, as amended, N.Y. ExecuTIVE LAW \$ 803 (McKinney 1974). The agency consists of eight members appointed by the Governor for terms of four years, together with two state cabinet commissioners and one subcabinet director serving ex officio. N.Y. Execurive LAw $\$ 803$ (McKinney 1974) [N.Y. ExEcurive LAw $\$ \$ 800-19$ (McKinney 1974) is hereinafter cited as Adirondack Plan Act]. It is aided by a staff that includes specialists in land planning, law, ecology, economics, and other disciplines. N.Y. Adirondack Park AgENCY, ANNUAL Report 197374 , at 7 .

15. Ch. 706, $\$ 806$ [1971] Laws of N.Y., 194th Sess. 1857, as amended, Adirondack Plan Act $\$ 815$.

16. Adirondack Plan Act $\$ 805$. The plan was to include a map that would divide such "Iands into areas and by accompanying text establish the intensity (including the type, character and extent) of the land use and development permissible within each area." Id. The map the agency submitted in 1973 now has the status of a legislative enactment. $I d$.

17. See Adirondack Plan Act $\$ \S 805-11$; N.Y. Adirondack Park Agency, Adirondack Park Land Use and Development Plan and Recommendations for Implementation 2-26 (1973). The substance and for the most part even the language are virtually identical. For a discussion of the mechanisms of this statute and its impact, see Booth, The Adirondack Park Agency Act: A Challenge in Regional Land Use Planning, 43 Geo. WASH. L. REV, 612 (1975).

18. The Future of the Adirondack Park, supra note 4, at 30. 
the commission's recommendations in this regard. Its regulatory effect is achieved by requiring approval for all new land uses falling within an expansive category defined by the statute itself. ${ }^{19}$ The entire authority is at first vested in the Adirondack Park Agency; a slice of this authority-concerning new uses on a smaller scale and deviating less sharply from prior use-is later to be transferred to the region's local governments on an individual basis. ${ }^{20}$ In order to receive this slice, a town or village government must submit for agency approval a "local land use program" 21 which promises to employ roughly the same criteria governing the agency's own review of projects, and which also contains adequate provisions for administration and enforcement. ${ }^{22}$ The agency retains certain supervisory powers with regard to local government programs after approving them, ${ }^{23}$ and in unusual circumstances can even revoke an approval previously given. ${ }^{24}$ Whether or not a locality has a program approved by the agency in force, it can make any regulation consistent with the statute; agency approval of a proposed land use will not make legal a use which does not comply with all applicable local regulations. ${ }^{25}$

\section{B. Principal Devices}

The statute requires that proposed land uses falling within the agency's review authority satisfy four criteria. ${ }^{20}$ The first criterion is

19. Adirondack Plan Act $\S \S 809.2,808.2$. Whether or not a proposed use falls into this category depends upon its proposed location as well as on what it is; the act makes reference to the Adirondack Park Land Use and Development Plan Map given effect in $\$ 805.2$. Id. $\$ 810$. In the most strictly regulated areas, approval is necessary even for so small scale a project as a two-lot subdivision or the construction of one single family dwelling. Id. $\$ \$ 810.1 . \mathrm{e}(3), 810.2 . \mathrm{d}(1)$. But in the least restricted areas neither a 99 lot subdivision nor a cement plant would require approval. See $I d . \$ 810.1 . a$.

20. Adirondack Plan Act $\$ 809.1$. The overall category of projects needing review is divided into two subcategories, "Class $A$ " and "Class B." See generally id. $\$ 810$. "Class $A$ " projects are those for which agency approval will always be required, whereas "Class B" projects are those for which agency approval is now required, but for which only. local government approval will be required when the local government has operating an agency approved program. Id. $\$ \$ 809.1,809.2,807$. As of June, 1975, no town or village had an agency approved program and the distinction between "Class $A$ " and "Class B" projects was therefore without practical effect. Interview with G. Gordon Davis, counsel for the Adirondack Park Agency, June 22, 1975 (telephone).

21. Adirondack Plan Act $\$ \$ 809.1,807$. The program must include "land use controls, such as zoning and subdivision regulations and building codes," and cover all land within the local government's jurisdiction. Id. $\$ 802.32$.

22. Id. $\$ 807.2$.

23. The agency retains permanent "standing to participate as a party" in the local government's consideration of any "Class B" project, and also judicial standing to challenge the issuance of a permit for any such project. Id. $\$ 808.2$. The agency retains in addition the power to reverse variances material to the plan it submitted to the legislature in 1973 and not adequately based on considerations of practical difficulty or unnecessary hardship. Id. $\S \S 808.3,802.29$.

24. Id. $\$ 808.4$.

25. Id. \$ 818.1.

26. Adirondack Plan Act $\S \S 809.10,809.9$, 807.2. The discussion to follow will presuppose the present situation-that all the project review authority under the statute 
that the proposed use "be compatible with the character description and purposes, policies and objectives of the land use area wherein it is proposed to be located." 27 In enacting the plan submitted to it by the agency, the legislature adopted a map of the park which in the manner of a traditional zoning map divides all the private lands into six "land use areas." 28 Provided for each of these areas is a statement of general intent and a list of "compatible uses." ${ }^{29}$ A principal aim of this first criterion, as it applies to 87 percent of the park's private land area, is "to prevent strip development along major travel corridors in order to enhance the esthetic and economic benefit derived from a park atmosphere along these corridors."30 Vigorous application of the "compatible use" list should concentrate new tourist establishments in or near town centers instead of allowing them to string along the open road. ${ }^{31}$

The second criterion is that the use "be consistent with the overall intensity guideline for the land use area involved." 32 Such "guidelines" are provided for four of the six land use areas, in which they

is still vested in the Adirondack Park Agency. See note 20 supra. Whereas the statute does not require that a project specifically meet these criteria if the project is within a locality operating under an agency approved local program, it does require that agency approval of local programs be premised upon their "reasonably" employing these same criteria. Id. $\$ 807.2$. The statute lists a fifth criterion, that the project "be consistent with the land use and development plan," id. $\$ 809.10$.a; but a comparison of $i d$. $\$ \S 802.29$, 805, and 806, and N.Y. Adirondack PARK AgENCY, Adirondack PARK LANd Use ANd DEVELOPMENT PLAN AND RECOMMENDATIONS FOR IMPLEMENTATION (1973), shows it to be redundant in relation to the other four.

27. Adirondack Plan Act $\$ 809.10 . \mathrm{b}$.

28. Id. \$ 805.2; Cartographic Services Section of the N.Y. State Office of Planning Services, Adirondack Park Land Use and Development Plan (rev. ed. 1974) (map) [hereinafter cited as ADIRONDACK PLAN MAP].

29. See Adirondack Plan Act $\$ 805$. Id. $\$ 809.10$.b provides that "[i]f the project is on the classification of compatible uses list for the land area involved, there shall be a presumption of compatibility with the character description, purposes, policies and objectives of such land use area," and an opposite presumption otherwise. These lists function in a manner analogous to, though looser than, traditional zoning use regulations.

These lists show that the statute is most concerned with regulating uses related to the enjoyment of the Adirondacks' scenic and natural qualitics. A comparison of $I d$. $\$ \$ 805.3 . \mathrm{d}(4)$ and $805.3 . \mathrm{g}(4)$ shows that as one passes from the least restrictive area to the most restrictive, such uses as tourist accommodations, tourist attractions, marinas, boat launching sites, commercial or private airports, mobile home courts, and hunting and fishing cabins greater than 500 square feet in area progressively drop off the lists, while such uses as agriculture, timber harvesting, mining, private sand and gravel extraction and "wood using facilities" like sawmills and chipping mills stay on to the end. Vacation homes are "compatible" in the most restrictive area as well, but the density restrictions discussed below greatly restrict their numbers there.

30. Id. $\$ \$$ 805.3.f(2), 805.3.g(2); statistics supplied by Anita L. Riner, Senior Natural Resources Planner, Adirondack Park Agency (on file with Yale Law Journal) (hereinafter cited as Riner Statistics] (the number of acres in each land use area, and its percentage of the park's total private acreage other than water surface). "Resource management areas," $\$ 805.3 . \mathrm{g}$, comprise about $1,718,000$ acres or 53.2 percent of the total; "rural use areas," $\$ 805.3 . \mathrm{f}$, comprise about $1,085,000$ acres or 33.7 percent.

31. Tourist accommodations and commercial uses generally are not on the compatible uses lists applicable to $\mathbf{5 3}$ percent of the park's private land area, while "tourist" attractions" are off the lists for 87 percent. Adirondack Plan Act $\$ \S 805.3 . f(4), 805.3 . g(4)$; Riner Statistics, supra note 30 .

32. Id. $\$ 809.10 . c$. 
govern building densities. ${ }^{33}$ They do not constitute minimum lot sizes, since an owner is permitted to subdivide his parcel into building lots however he wishes so long as the overall density allotment applicable to it is observed in the aggregate. ${ }^{34}$ The densities permitted over most of the park are in keeping with the region's rural, open space character: 53 percent of the park's private land is assigned a level of 15 new "principal buildings" 35 per square mile, or about one every 43 acres, while another 34 percent has been assigned a level of 75 per square mile..$^{36}$ Other areas of the park have been assigned less restrictive guidelines, and more than 100 separate, scattered areas, covering more than 80 square miles, have been assigned no density guideline at all. ${ }^{37}$ These less restricted areas are those which have thus far undergone the most development, and where most future development is expected to be concentrated..$^{38}$

The intent of the density guidelines appears to be to control vacation home development by channeling it into areas where it would least detract from those scenic and environmental qualities the vacation home buyers are themselves seeking. There appears to be no intent to depress the overall quantity of such development, inasmuch as the amount to be expected during the remainder of the century ${ }^{30}$

33. Id. $\S 805.3 . \mathrm{d}(3), . \mathrm{e}(3), . \mathrm{f}(3), . \mathrm{g}(3)$.

34. Id. $\$ 809.10$.c. For example, suppose that a person on the effective date of the statute owned a 150-acre parcel in the "rural use" land area, for which the intensity guideline is 75 principal buildings per square mile (about one every 8.53 acres). Id. $\$ 805.3 . \mathrm{f}(3)$; on "principal," see note 35 infra. His building allotment would be 18. He could sell off half his parcel to someone interested in constructing only one principal building and reserve for the remaining half the other 17 . He could then sell five one-acre lots, five eight-acre lots, and two 15-acre lots with one building right apiece.

35. The term "principal building" is given a complicated definition, the most important feature of which is that such accessory structures as garages and guest cottages associated with private residences are not principal buildings, though the residences themselves are. Id. $\$ 802.50$.

36. Id. $\$ 805.3 . f(3)$, .g(3); Riner Statistics, supra note 30 .

37. Adirondack Plan Act $\$$ 805.3.d.3, .e.3, .c.4, .h.4; Adirondack Plin Mar, supra note 28; Riner Statistics, supra note 30.

38. N.Y. Adirondack Park Agency, Adirondack Park Land Use and Development Plan AND Recommendations For IMPLEMENTATION 2,7 (1973).

39. The present park area contained about 22,000 seasonal residences in 1967. (In 1967 there were a total of 23,157 seasonal in all towns wholly or partially contained in the park-an area about five percent larger than the park itself. N.Y. TEMPORiRY STUdY COMM'N ON THE FUTURe OF THE ADIRONDACKS, TECHNICAL REPORT 1A, at 47, 53 (1970); Adirondack Plan MaP, supra note 28.) Growth in seasonal residences may be estimated by assuming that past national trends will continue and that the Adirondack area will at least roughly follow them. During the period from 1940 to 1967 , the average annual rate of vacation home construction nationwide increased by about 2000 per year-averaging 20,000 in the 1940 's, 40,000 in the 1950 's, and $55,000^{\prime}$ during the 1960-1967 period. U.S. Bureau of the Census, Dep't of Commerce, Current Housing Reports H-121 No. 16, Second Homes In the United States 10 (1969). The Adirondack Park's 1967 figure of roughly 22,000 vacation homes represented about 1.4 percent of the national total of $1,547,000$. If construction in the Adirondacks has followed this increase during the pait eight years there are now probably about 30,000 , and if it continues to follow it the total will grow by $\mathbf{3 7 , 0 0 0}$ by the turn of the century. This estimate may be a little 
is far below what the guidelines allow for. ${ }^{40}$

The third criterion which a proposed use must satisfy is that it "comply with the shoreline restrictions if applicable." 41 These restrictions regulate shoreline building densities, building setback, and the maintenance of vegetation along the shores of all lakes and ponds and certain rivers and streams. ${ }^{42}$

The fourth criterion is that the proposed use "not have an undue adverse impact upon the natural, scenic, aesthetic, ecological, wildlife, historic, recreational or open space resources of the [Adirondack] park or upon the ability of the public to provide supporting facilities and services made necessary . ..." 43 In effect this criterion gives the Adiron-

high in that the national figures are influenced slightly by the particularly large amount of vacation home construction taking place in the South. Id.

It does not appear that construction of new permanent residences will add greatly to this total of 37,000 . The present park area contained about 31,000 in 1967. (There were then a total of 32,841 in all the towns now wholly or partially within the park. Technical Report 1A, supra at 47,57.) The N.Y. Office of Planning Services estimates that during the 1970-1975 period the Black River-St. Lawrence and Lake ChamplainLake George Planning and Development Regions, which together contain the greater part of the Adirondack Park, will have grown in population by about 3.8 percent, and will grow by an additional 15.8 percent by the turn of the century. See N.Y. OFFICE of PlinNing Services, Demographic Projections 6 (1972). By pro rating this 3.8 percent 1970-1975 growth back to 1967 (thereby increasing it to 6.1 percent), and by assuming that the park population generally follows the trend of these two regions, and that growth in permanent residences reasonably follows population growth, one may estimate that the park now contains about 33,000 permanent residences and will contain an additional 5,000 by the turn of the century.

40. The Adirondack Plan Act does not place any upper limit on the number of residences (or other "principal buildings"-see note 35 supra) to be allowed in the park, since 80 square miles of the park's private land has been assigned no density guideline at all. See p. 1710 supra. Suppose that only half of this unrestricted territory is used for vacation homes at an intensity of two per acre; it can accommodate 51,000 homes. "Moderate intensity" areas, in which 500 principal buildings per square mile may be built, comprise about 99,000 acres and thus allow for 77,000 residences. Adirondack Plan Act $\$ 805.3 . d(3)$; Riner Statistics, supra note 30 . "Low intensity" areas, assigned a density level of 200 , comprise about 272,000 acres and thus allow for 85,000 residences. Adirondack Plan Act $\$ 805.3 . e(3)$; Riner Statistics, supra note 30. "Rural use" and "resource management" areas, assigned density levels of 75 and 15 respectively, comprise respectively about $1,085,000$ and $1,718,000$ acres, and thus allow for 127,000 and 40,000 residences. Adirondack Plan Act $\$ 805.3 . \mathrm{f}(3)$, .g(3); Riner Statistics, supra note 30 . The total number of residences allowed in these restricted areas is 329,000 , which when added to the 51,000 which may be contained in the unrestricted areas brings the grand total to 380,000 .

It should perhaps be noted that such uses as agriculture, timber harvesting, and mining are wholly compatible with density levels very much lower than 15 principal buildings per square mile, and are thus not affected by these guidelines.

41. Adirondack Plan Act $\$ 809.10$.d.

42. Id. $\$ 806.1$. These restrictions also govern the placement of septic systems near all bodics of water. Id.

43. Id. $\$ 809.10 . e$. The most important "supporting facilities" are roads. There are a limited number of highways in the Adirondacks and in the summer they become quite crowded. Significant expansion of the highway system-either through widening and lclocation of present highways, or through the construction of new ones-is constitutionally inhibited: state tracts protected by the "forever wild" clause of the N.Y. Con. stitution (art. XIV, $\$ 1$ ) are scattered throughout the park, and every major park highway passes through substantial portions of them. (See ADIrondack PLAN MAP, supra note 28.) Use of such territory for improving these highways is authorized under an exception to the "forever wild" clause that permits "relocating, reconstructing and maintaining a total of no more than fifty miles of existing state highways for the purpose of eliminating 
dack Park Agency power to add its own regulatory provisions to those of the statute, and to exert generally a discretionary control over the park's development. ${ }^{44}$ Pursuant to this power, the agency is preparing a set of development "guidelines" that cover matters that rarely or never before have been subject to regulation in this country: the preservation of wildlife habitats and feeding areas, and, in particularly scenic locations, the maintenance of tree growth sufficient to keep all development, including residences, invisible from a distance. ${ }^{45}$

The function of the four criteria is, simply stated, to prevent the park's "unique scenic, aesthetic [and] recreational . . resources"40 from becoming victims of their own attractiveness. The Adirondack program was not created without compromise. Its sharp regulation of uses which, like tourist establishments and vacation homes, depend to a large degree on the park's special character, is balanced by a relative tolerance of other economically important uses, in particular timber harvesting and mining. ${ }^{47}$ Although in many other regions the latter do enormous damage to the environment, they are at present neither great nor growing threats in the Adirondacks, especially when compared with the tourist trade and vacation homes, which, left unrestrained, tend to concentrate where they do the most harm. ${ }^{48}$

The Adirondack program does not promise complete preservation. But it does offer considerable protection against what may well be the principal threat facing every remaining scenic, natural region in the nation. It may be the only viable model for areas in other states for which the more complete protection of public ownership would be either too expensive or politically infeasible. One can therefore hope

the hazards of dangerous curves and grades, provided a total of no more than four hundred acres of forest preserve land shall be used for such purpose and that no single relocated portion of any highway shall exceed one mile in length," N.Y. Const. art XIV, § I. No "forever wild" territory at all may be used for the making of new highways. Id.; see Association for the Protection of the Adirondacks v. MacDonald, 253 N.Y. 234, 170 N.E. 902 (1930).

44. The only way in which the statute attempts to illuminate this criterion is through reference to a list of 37 items (e.g., "air quality," "noise levels," "scenic vistas," "geology," and "open space resources") that must be "considered" by the agency in determining whether or not a proposed land use has such an "undue adverse impact." Adirondack Plan Act $\S \S 809.10 . e, 805.4$. In addition to granting the agency a general rulemaking power, id. $\$ 804.9$, the legislature granted a special power to provide "further definition of [these 37 items] as they would apply ... in specific physical and biological conditions." Id. \$ 809.14.

45. Adirondack Park Agency, Draft of New 9 N.Y.C.R.R. pt. 582, Sept. 18, 1974 (unpublished) (on file with Yale Law Journal). The agency now quite frequently requires that vegetative screening be provided or maintained. Interview with Richard Estes, Director of Operations, Adirondack Park Agency, Dec. 19, 1974.

46. This phrase is a legislative "finding" concerning the park. Adirondack Plan Act $\$ 801$.

47. See notes 29,40 supra.

48. See THE FUTURE OF THE Adrondack PARK, supra note 4, at 26-29, 57-60; note 8 supra. 
that programs patterned on the Adirondack plan will some day receive widespread enactment. ${ }^{40}$

\section{Possible Constitutional Challenges to the Program}

The Adirondack program is well-designed not only to accomplish its regulatory aims, but to meet the kinds of challenges to environmentally oriented controls of land use which have been mounted in the past, with occasional success. Part I of this Note showed that the program addresses a well-defined need for regulation, and does so effectively. Our society has by now become sufficiently attuned to environmental concerns that there can be little question regarding the validity of a governmental interest in preserving our remaining scenic, natural areas. A state's regulatory authority extends to all measures reasonably related to the public welfare; ${ }^{50}$ the Adirondack program seems clearly to meet this test. But certain constitutional limitations apply even to land use regulations acknowledged to have

49. Some states have already taken steps in the direction of scenic and natural area preservation through control of private land use, but only Hawaii's Land Use Commission law, Hawail REv. Stat. ch. 205 (Supp. 1974), can be compared to the Adirondack Plan Act in comprehensiveness. See generally F. Bosselman \& D. Callies, The Quiet REVolution IN LAND USE CONTROL (also discussing Vermont's State Land Use and Development Plans law, VT. STAT. ANN. tit. 10, $\$ \$ 6001-89$ (Supp. 1974), the Colorado Land Use Act, Colo. Rev. Stat. ANN. $\$ \$ 24 \cdot 65 \cdot 101-05$ (1974), and the joint program established by California and Nevada to control development around Lake Tahoe).

The alternative to preserving scenic and natural lands through control of private use is through public acquisition. But reliance on such would not be practical for preservation on a national scale. The Adirondack Park covers an area greater than that of all the National Parks in the eight Rocky Mountain states combined-including Glacier, Yellowstone, Rocky Mountain, Grand Canyon, and seven others. See p. 1705 supra; World Almanac 713 (1975). An effective national preservation program would probably require public acquisition of an area at least as large as the Adirondack Park in New England, the Middle Atlantic states, and our eight other national "regions." The total cost of such a 60 million acre acquisition is hard to estimate: at $\$ 200$ an acre the total would come to $\$ I 2$ billion; at $\$ 1500$ an acre (the price paid by the National Park Service for acquisitions in 1971) the total would come to \$90 billion. See 5 UNITED States Nat'l Tourism Rev. Comm, Destination U.S.A. 53 (1973). It would in any event be very great and can be expected to rise steeply year by year.

An alternative might be the acquisition of less-than-fee interests on a regional scale. While such "scenic easements" might be a viable means of preserving isolated tracts, reliance on them on a regional basis would be impractical. Not only would the costs be great, and effective administration to ensure against fee owners' "cheating" nearly impossible, but the same problem would arise which caused the foundering of the various zoning-with-compensation schemes attempted before the decision in Village of Euclid v. Ambler Realty Co., 272 U.S. 365 (1926): landowners would announce all sorts of developmental intentions purely for the purpose of being bought off. See Waite, Governmental Power and Private Property, 16 CAru. L. Rev. 283, 287-88 n.7 (1967).

50. Duly enacted land use regulations have a "presumption of constitutionality"; anyone challenging them as arbitrary or unreasonable has the burden of proving such. Village of Euclid v. Ambler Realty Co., 272 U.S. 365 (1926). See 1 R. ANDERson, AMERICAN LAW OF ZoNING 67-68 (1968) and cases cited therein. Courts frequently add that "[i]f the validity of [a] legislative classification for zoning purposes be fairly debatable, the legislative judgment must be allowed to control." Village of Euclid v. Ambler Realty Co., supra at 388; R. ANDERson, supra at $72-75$ and cases cited therein. On a state's constitutional power to zone for esthetic purposes, see note 77 infra. 
a wholly rational basis. The ensuing discussion will concentrate on two issues raised within the case law that bear most directly on the Adirondack program and others that might be modeled after it: first, whether the program involves what has come to be called "exclusionary zoning," and, second, whether application of the program to particular properties results in a "taking" without just compensation. 51

\section{A. Exclusionary Zoning}

There has been an increasing number of challenges in recent years to zoning regulations whose effect is to exclude newcomers from the area in which they are applied. An important recent decision ${ }^{52}$ struck $^{2}$ down an ordinance in a township near Philadelphia which prohibited apartment houses altogether. The court found an intent to "freez[e] the population at near present levels,"53 despite the fact that the township was part of a rapidly filling suburban ring. The court reasoned that "if every municipality took that view, population spread would be completely frustrated." 54 There is nowhere in the opinion any mention of an economic loss to be suffered by the complaining landowner-the court was plainly more interested in the rights of a third party, the landowner's potential tenants: "This case deals with the right of people to live on land . ..." 55 The court noted that freezing

51. U.S. Consr. amend. V (applicd to the states through U.S. CoNsr. amend. XIV); N.Y. CoNsT. art. $1, \$ 7$. That the question of taking can arise after the rational basis of a statute has been affirmatively established is immediately illustrated by the one judicial decision to date dealing with a challenge to the Adirondack program itself. Sagolf Corp. v. Lawrence (N.Y. Sup. Ct., Essex County, Apr. 23, 1975). The court there explained its refusal to grant summary judgment in favor of the Adirondack Park Agency as follows:

$[T]$ he first allegation .... is that this statute is unconstitutional as applied to petitioner's property because the "low intensity" classification amounts to a confiscation or taking of petitioner's property without just compensation. In their answer, respondents have generally denied this allegation and have set forth an affirmative defense that the classification of lands made pursuant to [the Adirondack Plan Act] constitutes a valid exercise of the sovereign police power of the State of New York, within the framework of the State and Federal Constitutions. $A$ zoning law which confiscates property is a taking proscribed by the Constitution notwithstanding its tendency to serve the public health, safety, morals or welfare.

Id. at 4 (emphasis added).

The possible application of the taking issue to land use regulation in the Adirondachs was raised immediately upon the Adirondack Park Agency's submission of its plan (sce p. 1707 supra) to the legislature in 1973. Horn, Questions Concerning the Proposed Private Land Use and Development Plan for the Adirondack Park, 24 SY'RACUSE L. REY. 989,1003 (1973) (indicating that the taking issue might be a formidable obstacle, as it has been in the case of certain wetland protection statutes (see p. 1716 infra)).

52. Girsh Appeal, 437 Pa. 237, 263 A.2d 395 (1970).

53. Id. at 244,263 A.2d at 398 .

54. Id.

55. Id. at $245,263 \mathrm{~A} .2 \mathrm{~d}$ at 399 . See Construction Indus. Iss'n v. City of Petaluma, 375 F. Supp. 574 (N.D. Cal. 1974); Note, Freedom of Travel and Exclusionary Land Use Regulations, 84 YALE L.J. 1564 (1975). Several cases have dealt with this same issue in the context of challenges to large-lot zoning provisions. In National Land \& Inv. Co. 
the population of certain parts of a region would be permissible, if, as "in an ideal world, planning and zoning [were] done on a regional basis. . . . But as long as we allow zoning to be done community by community, it is intolerable to allow one municipality (or many municipalities) to close its doors at the expense of the surrounding communities and the central city." 56

An essential feature of the Adirondack program is that it embraces a whole region; it does not leave zoning up to the prejudices and caprices of local communities. Nor does the program inhibit the right of people to "live on land." Far from freezing the number of residences at its present 64,000 (including 30,000 seasonal), it allows for a 380,000 increase $^{57}$-whereas the most likely increase over the next 25 years is more in the neighborhood of 42,000 residences (including 37,000 seasonal). ${ }^{\text {ss }}$ Even if all the park's 5,781 square miles of private land ${ }^{50}$ were zoned to a density of 15 residences per square mile, this 42,000 figure could be accommodated more than twice over. A similar compatibility of low density zoning provisions with anticipated growth is to be expected in all regions which, like the Adirondacks, are vast in comparison with their population.

Often, the fundamental issue involved in an exclusionary zoning challenge is the discrimination wrought by provisions which as a practical matter prevent the entrance of less wealthy citizens. ${ }^{60}$ Not only are there scattered throughout the park significant areas without any

v. Easttown Township Bd. of Adjustment, 419 Pa. 504, 215 A.2d 597 (1965), the court invalidated a four-acre lot provision "whose primary purpose [was] to prevent the entrance of newcomers" in a town that found itself "in the path of a population explosion approaching from two directions." Id. at 532, 519, 215 A.2d at 612, 605. The court specifically cautioned against applying this case in situations unlike that of Easttown: "Every zoning case involves a different set of facts and circumstances in light of which the constitutionality of a zoning ordinance must be tested. Therefore, it is impossible for us to say that any minimum acreage requirement is unconstitutional per se." $I d$. at 523, $215 \mathrm{~A} .2 \mathrm{~d}$ at $607-08$. The leading nonsuburban large-lot zoning case is Steel Hill Dev., Inc. v. Town of Sanbornton, 469 F.2d 956 (1st Cir. 1972), in which a six-acre minimum lot size requirement was upheld. The court distinguished the Pennsylvania cases by noting that the developer "does not seek to satisfy" an already existing demand for suburban expansion, but rather seeks to create a demand in Sanbornton on behalf of wealthy residents of Megalopolis . . ."Id. at 961. Accord, County Comm'rs v. Miles, 246 Md. 355, 228 A.2d 450 (1966); cf. County Supervisors v: Carper, 200 Va. 653, I07 S.E.2d 390 (1959).

56. 437 Pa. at 245 n.4, 263 A.2d at 399 n.4.

57. See note 40 supra.

58. See note 39 supra.

59. See p. 1705 supra.

60. See, e.g., Southern Burlington County N.A.A.C.P. v. Township of Mt. Laurel, 67 N.J. 151, 174, 336 A.2d 713, 724 (1975) ("We conclude that every such municipality must, by its land use regulations, presumptively make realistically possible an appropriate variety and choice of housing. More specifically, presumptively it cannot foreclose the opportunity of the classes of people mentioned for low and moderate income housing and in its regulations must affirmatively afford that opportunity, at least to the extent of the municipality's fair share of the present and prospective regional need therefor.") 
density restriction, but there are no true minimum lot size requirements applicable anywhere. ${ }^{61}$

\section{B. Taking}

Although the Adirondack program plainly will enhance the enjoyment of those who choose to vacation in the Adirondacks, it will no doubt also cut down the size of profits to be made by some vacation home developers. This fact is likely to generate allegations that it results in a taking. Litigation on this issue has in fact already begun. ${ }^{02}$ When a court finds a taking, it rarely decrees the total invalidation of the land use regulation involved; it merely excuses a specific landowner from compliance on grounds of an excessive diminution of the value of his property. Yet the readiness of a court to grant such exemptions can as effectively nullify a regulation as an outright repeal. Many environmentally oriented regulatory provisions have been eviscerated in this fashion, ${ }^{63}$ most notably the wetlands protection ordinances set aside in Maine, Massachusetts, Connecticut and New Jersey. ${ }^{64}$

Although the exact measure of economic diminution seen as excessive may vary from state to state, certain fundamental principles appear to be universal. The first is that the mere showing that a land use regulation prevents a property from being put to its most

61. See p. 1710 supra.

62. See note 51 supra. Horizon Adirondack Corp.-a subsidiary of Horizon Corp. of Tucson, Ariz.--has filed an action in the New York Court of Claims for $\$ 36$ million on the grounds "that by reason of the enactment of [the Adirondack Plan Act], the State of New York has unjustly, illegally and unconstitutionally appropriated an interest in the aforesaid premises owned by the claimant and has substantially lowered the value thereof." Complaint at 8, Horizon Adirondack Corp. v. New York, No. 58949 (N.Y. Ct. Cl. Dec. 11, 1974). Horizon had announced plans for a 6,955 unit vacation home project on the property in question; the act's density guidelines allow for only 1,608 units. N.Y. Times, Dec. 12, 1974, at 21, col. 1.

63. See F. Bosselman, The Taking Issue 1-50 (1973).

64. Although the decisions on wetland regulations are divided in their result, they all express adherence to the deprivation test discussed p. 1717 infra. See Dooley v. Town Plan \& Zoning Comm'n, 151 Conn. 304, 309, 197 A.2d 770, 772 (1964) ("use of the plaintiffs' land has been, for all practical purposes, rendered impossible"; regulation set aside); State v. Johnson, 265 A.2d 711, 716 (Me. 1970) (owner of swamp excused from prohibition against filling under which the property would have "no commercial value whatever"); Commissioner of Natural Resources v. S. Volpe \& Co., 349 Mass. 104, 206 N.E.2d 666 (1965) (case remanded to determine whether land had value under regulation); Turnpike Realty Co. v. Town of Dedham, 284 N.E.2d 891, 894 (Mass. 1972), cert. denied, 409 U.S. 1108 (1973) (zoning bylaw prohibiting all structures and allowing only "woodland, grassland, wetland, agricultural, horticultural, or recreational use of land or water not requiring filling" sustained); Morris County Land Improvement Co. v. Township of Parsippany-Troy Hills, 40 N.J. 539, 557, 193 A.2d 232, 243 (1963) (ordinance designed to preserve certain extensive wetlands as flood retention basins set aside for having a "nullifying effect" upon "any productive use of property in the zone"); Just v. Marinette County, 56 Wis. 2d 7, 17, 201 N.W.2d 761, 768 (1972) (regulation sustained; landowners may constitutionally be restricted to "natural and indigenous" uses) (noted in 86 HARV. L. REv. 1582 (1973)). 
profitable or "highest and best" use is no grounds for relief from that regulation. ${ }^{65}$ Another is that applying the regulation may result in a significant or even great reduction of the property's value without being invalid on constitutional grounds. ${ }^{\circ 0}$ The limit seems to be approached only when the effect of the regulation nears the point of depriving the owner of the entire use value of what he owns. A formula well established in the great majority, if not virtually all, of the states is that "[t]o sustain an attack upon the validity of [an] ordinance an aggrieved property owner must show that if the ordinance is enforced the consequent restrictions upon his property preclude its use for any purpose to which it is reasonably adapted." 67

This standard is entirely consistent with programs which, like the Adirondack program, in no area seek to shut off development alto-

65. See 1 R. ANDERSON, supra note 50, at 85-87 and cases cited therein; cases cited in notes 66,70 infra.

66. Samp Mortar Lake Co. v. Town Plan \& Zoning Comm'n, 155 Conn. 711, 231 A.2d 649 (1967) (possible devaluation from $\$ 45,000$ to $\$ 8,000$ ); Board of Zoning Appeals $v$. Schulte, 241 Ind. 339, 349, 172 N.E.2d 39, 43 (1961); Louisville Timber \& Wooden Prods. Co. v. City of Beechwood Village, 376 S.W.2d 690 (Ky. 1964); Bureau of Mines v. George's Creck Coal \& Land Co., 272 Md. 143, 321 A.2d 748 (1974); Hoffmann v. Kinealy, 389 S.W.2d 745, 748-49 (Mo. 1965); Sibson v. State, 111 N.H. 304, 282 A.2d 664 (1971) (denial of permit to fill wetland, claimed devaluation from $\$ 158,000$ to $\$ 40,000)$; Chevron Oil Co. v. Beaver County, 22 Utah 2d 143, 146, 449 P.2d 989, 991 (1969); cases cited in note 67 infra; $1 \mathrm{R}$. ANDERSON, supra note 50, at $88-90$ and cases cited therein.

67. Arverne Bay Constr. Co. v. Thatcher, 278 N.Y. 222, 226, 15 N.E.2d 587, 589 (1938); Salamar Builders Corp. v. Tuttle, 29 N.Y.2d 221, 228, 275 N.E.2d 585, 590, 325 N.Y.S.2d 933, 939 (1972); Dauernheim Inc. v. Town Bd., 33 N.Y.2d 468, 472, 310 N.E.2d 516, 519, 354 N.Y.S.2d 909, 914 (1974); City of Phoenix v. Fehlner, 90 Ariz. 13, 19, 363 P.2d 607, 611 (1961); McCarthy v. City of Manhattan Beach, 4I Cal. 2d 879, 891-92, 264 P.2d 932, 939 (1953), cert. denied, 348 U.S. 817 (1954) (beach property restricted to recreational activities only; building of houses forbidden; restriction judged valid because complainant failed to show that the property "could not be put to beneficial use in conformity with the zoning limitation"); Norpo Co. v. Town of Cherry Hills Village, 504 P.2d 344, 349 (Colo. 1972); Ocean Villa Apartments, Inc. v. City of Fort Lauderdale, 70 So. 2d 901, 902 (Fla. 1954); Friedman v. Montgomery County Council, $247 \mathrm{Md}$. 197, 203, 230 A.2d 65I, 653 (1967); Abbott v. Appleton Nursing Home, Inc., 355 Mass. 217, 223, 243 N.E.2d 912, 917 (1969); Township of White Lake v. Amos, 371 Mich. 693, 698, 12.4 N.W.2d 803, 805 (1963); Flanagan v. Town of Hollis, il2 N.H. 222, 223, 293 A.2d 328, 329 (1972); Bow \& Arrow Manor, Inc. v. Town of West Orange, 63 N.J. 335, 350, 307 A.2d 563, 571 (1973); Helms v. City of Charlotte, 255 N.C. 647, 653, 122 S.E.2d 817, 820, 822 (1961); Tidewater Oil Co. v. Poore, 395 Pa. 89, 97, 149 A.2d 636, 640 (1959); DuBois v. Zoning Bd. of Rev., 101 R.I. 461, 463, 224 A.2d 606, 607 (1966); City of EI Paso v. Donohue, 352 S.W.2d 713, 717 (Tex. 1962); Just v. Marinette County, 56 Wis. 2d 7, 15, 201 N.W.2d 761, 767 (1972).

The preceding cases do not call for a balancing of the diminution in property values caused by the regulation against the resulting public benefit. In certain other leading state court cases balancing does seem to have taken place. Samp Mortar Lake Co. v. Town Plan \& Zoning Comm'n, 155 Conn. 310, 231 A.2d 649 (1967); LaSalle Nat'l Bank v. City of Evanston, 24 Ill. 2d 59, 63, 179 N.E.2d 673, 675 (1962); State v. Johnson, 265 A.2d 711, 716 (Me. 1970); Bach v. Sarich, 74 Wash. 2d 575, 445 P.2d 648 (1968).

For discussion of this test, see Michelman, Property, Utility, and Fairness: Comments on the Ethical Foundations of "Just Compensation" Law, 80 HARv. L. REv. 1165, 1190-93, $1229-34$ (1967); Heynan \& Gihool, The Constitutionality of Imposing Increased Community Costs on New Suburban Residents through Subdivision Exactions, 73 YALE L.J. 1119, 1124-25 (1964); Waite, Governmental Power and Private Property, 16 CatH. L. Rev. 283, 289.91 (1967). 
gether or to keep any property essentially unused, but which seek rather to control the manner in which development occurs. ${ }^{98}$ This standard is also favorable to conservationist land use controls in areas where most lands are devoted to uses from which the expected economic return is lower than that in more highly developed areas. The uses to which a property is "reasonably adapted" depend of course upon its location. Although this test would find a typical property in Manhattan unduly restricted if it could be used only for single family houses, the same could not be said of a typical property in Connecticut. An obvious indication that a property is reasonably adapted to a given use is that similar properties throughout its region rely on that use as a means to a profit.

In the Adirondacks, about 80 percent of all private acreage is devoted exclusively to such open space uses as general farming, dairy farming, timber harvesting, orchards, and private forest and game preserves; only about 10 percent is residential (including vacation home properties) ${ }^{69} \mathrm{~A}$ similar situation no doubt exists in many other relatively undeveloped areas. A strictly literal application of the test would countenance a regulation limiting all normal properties to the open space uses just mentioned, and barring such uses as new vacation homes altogether. ${ }^{70}$

There of course exist atypical Adirondack lands-ones for which such uses as vacation homes constitute the only reasonably practical source of an economic return, the regionally predominant uses being ruled out by the property's small size, soil conditions, or other factors. For such lands, the question of confiscation will turn on whether the density guidelines and other regulations permit a number of vacation homes such that some reasonable value may be realized. ${ }^{71}$ If

68. See pp. 1709-12 supra, note 71 infra.

69. See Technical Report 1A, supra note 39, at 49. Such open space uses are important to the regional economy. See N.Y. Temporary STUdY Comm'N on THE FUtrRE of THE Adirondacks, Technical Report 4, at 20 (1970).

70. A corollary of such a strict interpretation is that a legislature can constitutionally freeze the land use characteristics of a region so long as property owners are able to earn a reasonable profit, and permit no real estate development whatever for most if not all properties. Cases upholding extremely severe restrictions on development include Turnpike Realty Co. v. Town of Dedham, 284 N.E.2d 891 (Mass. 1972) (discussed in note 64 supra); Kilfeather v. Town Bd., 43 Misc. 2d 328,250 N.Y.S.2d 599 (Sup. Ct. 1964) (lot too small for any building under ordinance; validly restricted to agricultural and nursery uses); Chevron Oil Co. v. Beaver County, 22 Utah 2d 143, I46, 449 P.2d 989,991 (1969) (property worth $\$ 20$ or $\$ 30$ an acre under restriction as "grazing area," $\$ 10,000$ an acre if highway services allowed: "Plaintiffs are not deprived of their property. They bought grazing land, and they still own grazing land."); Just v. Marinette County, 56 Wis. $2 \mathrm{~d} 7,201$ N.W.2d 761 (1972) (discussed in note 64 supra).

71. The density guidelines of the Adirondack program are suspended in the case of lots too small for an allotment of one "principal building" (see note 35 supra) to the extent of allowing the construction of one single family dwelling or mobile home. 
large lots will bring a reasonable return, then there is no taking, even if smaller lots would bring more money. ${ }^{22}$

While the standard for taking will probably sustain application of the Adirondack program's various control measures in all but a small minority of cases involving atypical properties, there is a line of judicial decisions which might reduce even this small minority. These decisions essentially place no limits on the allowable diminution of a property's value where ( 1 ) the property is devoted to a given use and is set in the midst of other properties which are seriously harmed by that use, and (2) the regulation imposes no greater burden than that the property be used in the manner of those surrounding it, or at least to cease causing the harm to them it is now causing. The second condition means that the regulation imposed on the property seen as offending is, considered in itself, no more onerous than the regulations imposed on the neighboring properties: nothing is forbidden on the former that is permitted on any of the latter. It is not that a given property is being singled out for the imposition of a special mode of use, but rather that neighborhood harmony in land utilization practices is being enforced. ${ }^{73}$ This kind of regulation is sustained even in cases where it renders the offending property worthless or nearly so, being justified by the strong analogy to nuisance abatement. Along with decisions upholding regulations directed against

Adirondack Plan Act $\$$ 811.1.a. Similarly exempted are lots generated by subdivisions resulting from bona fide gifts, devises, and inheritances. $I d$. $\$ 811.1 . c$. There is also an exemption for subdivisions for which all approvals required by law had been obtained prior to the Act's becoming effective. $I d . \$ 811.3$.

72. Even though landowners have no constitutional right to an economic return equal to what their properties would bring were use of them unregulated, frequently when a new land use regulation goes into effect developers and other landowners claim to have suffered a loss as a result of the restrictions imposed. Such claims of "loss" are often misleading, for the "Ioss" is usually figured on the assumption that neighboring lands will be maintained in a condition enabling the landowner to realize his hoped-for high return. A property can most profitably be used for vacation homes only if neighboring properties are maintained in a condition harmonious with vacation home living. But absent a set of restrictions like those contained in the Adirondack program, such an assumption would be illusory. If a developer or other landowner complains of a "loss" suffered because his property is worth less regulated than unregulated, he must be asked how much it would be worth were all properties around it unregulated also. A program which like the Adirondack program preserves the attractiveness of the region for vacation home dwellers ought in the long run to cause an overall gain in vacation home property values.

73. The cases discussed in notes 74-77 infra are for this reason to be distinguished from the well-known New York "taking" case of Vernon Park Realty, Inc. v. City of Mount Vernon, 307 N.Y. 493, 121 N.E.2d 517 (1954). There the city government, worried over plans by the owner to convert the only large parking area near the city's principal railroad station into a shopping center, rezoned the area limiting its use to automobile parking and related services only. The court found this to constitute "placing an undue and uncompensated burden on the individual owner of a single parcel of land in the guise of a regulation." Id. at 498,121 N.E.2d at 519 . 
safety hazards ${ }^{74}$ or such traditional nuisances as dust and noise, ${ }^{75}$ there are others extending this same principle to harms of another sort: one upheld a general prohibition of industrial development, ${ }^{, 0}$ another a set of billboard regulations. ${ }^{77}$

In the Adirondacks, many land uses which are accepted in urban or suburban neighborhoods can be considered harmful. These are

74. In Erie R.R. v. Board of Pub. Util. Comm'rs, 254 U.S. 394 (1920) (Holmes, J.), the Court upheld a state board's power to order railroad companies at their own expense to eliminate, by building suitable viaducts, grade crossings involving public roads, even where the road involved was laid out long after the tracks, the latter being private. In response to the Erie Railroad's plea "that if the same requirement were made for its other grade crossings it would soon be bankrupt," Justice Holmes said for the majority: "That the states might be so foolish as to kill a goose that lays golden eggs for them, has no bearing on their constitutional rights. If it reasonably can be said that safety requires the change it is for them to say whether they will insist upon it, and neither prospective bankruptcy nor engagement in interstate commerce can takc away this fundamental right of the sovereign of the soil." Id. at $410-11$. See also Goldblatt v. "Town of Hempstead, 369 U.S. 590 (1962), aff'g 9 N.Y.2d 101, 172 N.E.2d 562, 211 N.Y.S.2d 185 (1961). Holmes's opinion in Erie is hard to square with the one he wrote in Pennsylvania Coal Co. v. Mahon, 260 U.S. 393 (1922). For a thorough criticism of the latter case, see F. Bosselman, The Taking Issue 51-138 (1973).

75. E.g., Consolidated Rock Prods. y. City of Los Angeles, 57 Cal. 2d 515, 519, 370 P.2d 342, 344, 20 Cal. Rptr. 638, 640, appeal dismissed, 371 U.S. 36 (1962) (upholding an ordinance barring sand and gravel extraction on the complainant's land despite the trial court's finding it "preposterous" that "the property has economic value for any other use.") See also Hadachek v. Sebastian, 239 U.S. 394 (1915).

The idea that in situations where potential harms are involved the issue of economic deprivation can be ignored has been noted by several scholars. Professor Michelman states that the economic issue does not arise in decisions sustaining curbs on "noxious" or "nuisance-like" uses of property: "[T]hese may, it seems, be quelled by public authority without any compensation for huge losses represented by nearly total devaluation of holdings." Michelman, supra note 67, at 1191. Professor Kusler points out that the standard for taking becomes inoperative in situations where all the uses to which the property in question is reasonably adapted are nuisance-like. Kusler, Open Space Zoning: Valid Regulation or Invalid Taking, 57 MINN. L. REv. 1, 47 (1972). See also Note, State and Local Wetlands Regulation: The Problem of Taking without Just Compensation, 58 VA. L. REv. 876, 891 (1972).

76. Filister v. City of Minneapolis, 270 Minn. 53, 133 N.W.2d 500 (1964), cert. denied, 282 U.S. 14 (1965).

77. St. Louis Poster Advertising Co. v. City of St. Louis, 249 U.S. 269 (1919) (Holmes, J.). The Court accepted as a basis for its decision the complainant's various assertions, including that enforcement of the ordinance would "put appellant out of business by destroying its ability to accept ... business offered it, by making its leases worthless, and would amount to a destruction of the entire property acquired and used by it ...." St. Louis Poster Advertising Co. v. City of St. Louis, 195 S.W. 717, 720 (Mo. 1917). Sec 249 U.S. at 273.

The early cases upholding billboard regulations exemplify the manner in which zoning for esthetic objectives has been handled by many American courts for the past 60 years. They have paid lip service to the supposed principle that regulations motivated purely by esthetic considerations are not within the scope of the police power, while sustaining regulations obviously so motivated on grounds that their esthetic purpose is complemented by some purpose related to public health or safety, even when this purpose seems at best unconvincing and at worst wholly frivolous. See, e.g., Thomas Cusack Co. v. City of Chicago, 242 U.S. 526, 592 (19I7) ("[Billboards] afford a convenient concealment and shield for immoral practices, and for loiterers and criminals."); Dukeminier, Zoning for Aesthetic Objectives: A Reappraisal, 20 LAw \& ConTEMP. ProB. 218,223 (1955). A few courts, though, have now ceased to play such a word game, and are openly admitting that esthetics alone are a valid zoning objective. People v. Stover, 12 N.Y.2d 462, 467, 191 N.E.2d 272, 275, 240 N.Y.S.2d 734, 738, appeal dismissed, 375 U.S. 42 (1963); Oregon City v. Hartle, 240 Ore. 35, 49, 400 P.2d 255, 262 (1965); State v. Diamond Motors, Inc., 50 Hawaii 33, 36, 429 P.2d 825, 827 (1967). 
uses which interfere with local living patterns, and consequently with property values, no less than dust, noise, factories, and billboards in more built-up locations. ${ }^{78}$ Imagine a number of landowners who together own a mountain lake and all the surrounding shore. Each has a cabin, well set back and screened by vegetation, so that the shoreline itself is pure forest and the entire lake secluded and tranquil. One of the landowners sells some of his shore frontage to a developer who proceeds to construct several large, modern housesor, worse still, a single resort hotel-right next to the water. ${ }^{79} \mathrm{~A}$ regulation limiting properties around this lake to cabins would prevent a harm to the neighborhood while treating all properties alike.

Even if courts should refuse to extend the principles set forth in this line of safety and nuisance cases to decide "taking" challenges launched against the Adirondack program, the "taking" issue should not constitute an important obstacle. For the question in every instance will not be whether a property can be developed, but rather to what extent and in what manner. It will therefore be difficult for a complaining landowner to show that he is not able to put his land to any use for which it is "reasonably adapted." Any land preservation program which incorporates this feature of the Adirondack program is likely to possess a similar immunity.

78. Courts have long held that the harmfulness of a land use is to be determined in reference to its location. See Village of Euclid v. Ambler Realty Co., 272 U.S. 365, 388 (1926) ("A nuisance may be merely a right thing in a wrong place-like a pig in the parlor instead of the barnyard.")

79. This development would be a violation of the shoreline restrictions. Adirondack Plan Act $\$ 806$; see p. 1711 supra. 